\title{
Strategies of investigating and translating poetical prose of the classical and contemporary English short stories
}

\author{
Alexander Yemets*, Anastasiia Zakharchuk ${ }^{1}$ \\ ${ }^{1}$ Department of Germanic Philology and Translation Studies, Khmelnytskyi National University, \\ Khmelnytskyi, Ukraine
}

\begin{abstract}
The article considers the notion of prose poeticalness from linguistic and translation points of view. Prose poeticalness can be defined as the introduction of poetic features into the prose text with the help of such devices as extended metaphors, intertextual allusions, stylistic convergence, syntactical and phonetic repetitions. The investigation involved the analysis of the fairy tales by Oscar Wilde, the short stories by Kate Chopin and Dylan Thomas, which are referred to as classical prose, and the contemporary American flash fiction stories. The strategy of investigating prose poeticalness involved determining the devices of prose poeticalness in each text, defining the linguistic and stylistic components of these devices and their functions. As a result of our research, it is determined that the most foregrounded device of poeticalness is stylistic convergence. In the classical short stories, convergences function in bigger text fragments, they are based on the extended antropomorphic metaphors or similes in the interaction with alliterations. The stylistic convergences are used for poetical description of nature as human beings possessing the ability to speak, to think, to love (Wilde, Thomas), and even as gods (Rob Carney). Biomorphic tropes are used as the core of convergences, as a device of poetical description of people in the stories by Thomas, fairy tales by Wilde, in the flash fiction stories by John Updike, Grace Paley, Leigh Wilson and other writers. In the contemporary flash fiction stories, convergences foreground the ideas of sympathy, tolerance; they help to create a strong emotional effect. The strategy of rendering stylistic convergences in translation of the poetical prose consists in the exact reproduction of images applying literal translation or synonymic substitution and retaining the sound effect in trope components. Mythological and biblical allusions used as a system in the text are a device of poeticalness typical for Thomas's stories. The strategy of translating implicit allusions involves retaining the intertextual comments and giving explication in the text or in the footnotes. It is suggested that the prospects of further research lie in investigating poeticalness in the novels of contemporary writers.
\end{abstract}

${ }^{*}$ Corresponding author: yemetsov@ukr.net 


\section{Introduction}

While reading the fairy tales by Oscar Wilde, the short stories by Kate Chopin, Ernest Hemingway, Dylan Thomas, Virginia Woolf, Ray Bradbury or the novels by John Updike or John Fowles, we experience different emotions - sympathy, sadness or joy. In addition, we experience aesthetic pleasure, the feeling which Roland Barthes called "le plaisir du texte" (the pleasure of the text) [1: 462]. It can be explained by the fact that the prose of these writers is imaginative, emotional, and thought-provoking. The effect produced by these and similar literary masterpieces was well described by Erza Pound in relation to a literary image "that gives that sense of sudden liberation; that sense of freedom from time limits and space limits; that sense of sudden growth which we experience in the presence of the greatest works of art" [2: 64]. Very often, such prose texts are called poetical. But how to objectively determine such feature as poeticalness of prose? And how to translate such prose in order to retain the features of poeticalness?

As the article deals with literary prose, it is necessary to briefly determine the major peculiarities of such texts. As distinct from the texts of other styles, literary texts are distinguished by specific features. Such features involve different types of foregrounding (parallelism, metaphors, and allusions), rhythm, emotional character of narration. According to Theo Hermans [3: 79], the following features of literary texts can be singled out: the foregrounding of language, the interdependence of different levels of linguistic organization, the perception of the texts as both aesthetic objects and intertextual constructs. Klaudia Bednarova-Gibova justly states that "the most important feature of a literary text is that it is a bearer of an aesthetic function" [4: 29].

The priority of aesthetic function in poetry and prose makes it necessary to consider the major similarities and differences between the two genres. The opposition of these genres of literature is not absolute; the development of poetry and prose leads to their interconnection and mutual influence. Poetry and prose have peculiar intermediate forms, like poems in prose by Oscar Wilde. Another intermediate form is poetical prose. Poetical prose is the manifestation of poeticalness, one of the major notions of poetics. Roman Jakobson regarded poetics as a linguistic discipline. Jakobson defined poetics as that part of linguistics, which treats poetic function in its relationship to other functions of language [5: 359]. Thus, the dominance of poetic and aesthetic functions in a literary text can be the sign of poeticalness, the feature of a poetical text.

The significance and novelty of our research lie in the fact that there has been no detailed analysis of prose poeticalness in the British and American literature, especially in the contemporary short stories. Therefore, our paper presents the first comprehensive investigation of poetical prose from linguistic and translation viewpoints. Also, the novelty lies in the fact that our research shows the role of the stylistic device of foregrounding in creating prose poeticalness.

The aim of the paper is to characterize the features (devices) of prose poeticalness in the classical and contemporary short stories and to determine the strategies and techniques of rendering these devices in translation. The investigation is based on the short stories of Kate Chopin, Dylan Thomas, the fairy tales by Oscar Wilde, and the contemporary flash fiction stories written after 2000.

In our article we analyze the translation of Oscar Wilde's fairy tales by the well-known Ukrainian translator Dariya Radienko; two stories by Kate Chopin translated by the students of our department Yuliya Dudchak and Alla Slisarenko were published in the Ukrainian literary magazine Vsesvit. As for Dylan Thomas's short stories, they have never been translated into Ukrainian except "The Tree". In this paper we characterize the existing Russian translations and suggest our own variant for comparative analysis. Four contemporary flash fiction stories are translated by the authors of this article. Flash fiction 
stories become increasingly popular in modern literature. The main feature of flash fiction stories is brevity because they contain 500-1000 words, i.e. 2-3 pages long. Nevertheless, flash fiction stories are characterized by the variety of stylistic devices, especially stylistic convergence and extended original metaphor, creating the poeticalness in the text.

\section{Methods of research}

The methodology of investigating the stylistic and translation aspects of poeticalness of prose included the following procedures. First, we characterize the main devices of creating poeticalness. The underlying lexical and stylistic means which realize the device of poeticalness are singled out. Next, their pragmatic functions in the text fragment or in the whole text are determined. The second procedure, i.e. the translation procedure, includes several stages as well. At first, we apply the vertical translation. We coined this term in association with vertical reading suggested in our monograph [6: 21]. Under vertical translation we mean reading the text (text fragment) vertically, not horizontally, that is sentence after sentence, and finding text anomalies, i.e., language units, collocations, sentences which contain elements difficult for translation. Such elements can involve original metaphors, allusions, paradoxes, neologisms, sound repetitions. The second stage includes the translation of these elements separately, taking into consideration the existing lexical and stylistic devices of translation. The third stage consists in uniting all these elements into the connected text and editing the text according to the context. After this procedure, it is possible to formulate the strategies and techniques of rendering such complex and comprehensive stylistic and poetical phenomenon as poeticalness of prose. Similar procedures can be applied in the comparative analysis of the source and target texts.

The methods applied in our research involve the method of contextual analysis for determining the meanings of the language units in convergences, the method of stylistic analysis for characterizing the types of stylistic devices creating the effect of prose poeticalness, the method of comparative analysis for determining the techniques of reproducing the devices of poeticalness in the Ukrainian translation.

Let us illustrate the suggested algorithm of analysis with the fragment from the worldknown literary fairy tale "Through the Looking-Glass" by Lewis Carroll:

"Do you hear the snow against the window-panes, Kitty? How nice and soft it sounds! Just as if someone was kissing the windows all over outside. I wonder if the snow LOVES the trees and fields, that it kisses them so gently? And then it covers them up snug, you know, with a white quilt; and perhaps it says, 'Go to sleep, darlings, till the summer comes again'"' [7: 8].

This small fragment is not so typical of Carroll's style with its paradoxes, puns and lexical deviations. However, it produces a poetical, aesthetic and emotional effect. The snow is described with the help of the extended anthropomorphic metaphor which unites one simile and four metaphors of conceptual character SNOW IS HUMAN BEING. Another important feature of the fragment is the multiple repetition of the sound [s], mainly sound anaphora. The function of the alliterations can be interpreted as emphasizing the main elements of the utterance snow-sound-kiss, and some onomatopoeic effect as if this repetition imitates a soft sound of the falling snow. The emotional aspect is realized by the use of the evaluative words in the girl's speech: love, kiss, and darlings.

The translator Valentyna Narizhna skillfully rendered the imagery: "Чуєш, як сніг шурхотить по шибках, Кицю? Який приємний, м'який звук ! Ніби хтось обціловує вікна ззовні. Цікаво, виходить, сніг ЛЮБИТЬ дерева і поля, якщо цілує їх так ніжно? А тоді він, уявляєш, укриває їх затишненько білою пуховою ковдрою i, можливо, навіть каже: “Засинайте, дорогенькі, поки знову не прийде літо” [7: 9]. 
The emotional effect is enhanced by means of the words with diminutive suffixes: затишненько; дорогенькі. However, the alliterations are not reproduced in the target text, except the first sentence. But in general the translator managed to retain the poeticalness, the tender attitude of the girl to nature. Thus, the abovementioned methodology of analysis and translation of poetical prose texts or their fragments will be applied in our further research.

\section{Research Results}

In the opinion of W.Noth, for Roman Jakobson, poeticalness is the synonym of poetic function [8]. But the notion of prose poeticalness, from linguistic point of view, was first deeply investigated by the German scientist Wolf Schmid. Schmid defined this notion as the introduction of certain poetic features into a prose text with the help of three major devices of text organization, such as: a) the introduction of mythical (mythological) thinking and the use of extended metaphors; b) the text paradigmatization; c) the use of intertextual allusions [9: 210-214]. Mythological thinking is realized by means of tropes; paradigmatization is understood as creating the system of similarities and contrasts in the text. Intertextual allusions make the text polysemantic, like in poetry. This conclusion was made on the basis of the collection of short stories "Povesti Belkina" by the Russian writer Olexander Pushkin. It was the so-called "poet's prose". And the stories were written nearly 200 years ago.

But the twentieth and twenty-first centuries brought significant changes in the theory of stylistics, in poetics, in the metaphoric paradigm. The Russian formalists (V.Shklovsky, R.Jakobson) and the Prague school of linguistics developed the theory of foregrounding which became the foundation of modern stylistics. J.Mukajovsky defines the poetic function in the following way: "The function of poetic language consists in the maximum foregrounding of the language. Foregrounding is the opposite of automatization that is deautomatization of the act" [8: 356]. The scientist states that the more foregrounded the utterance is, the more conscious it becomes. According to John Douthwaite, foregrounding is a general linguistic technique by which a marked linguistic technique is produced [10: 93]. In modern stylistics, foregrounding is characterized as such ways of text organization, which focus the reader's attention on certain elements of the message [11: 99]. Geoffrey Leech formulated two aspects of foregrounding - qualitative, which concerns the deviation from the language norm, and quantitative, which implies the deviation of the expected frequency. The quantitative aspect of foregrounding results in redundancy, i.e. frequent use of tropes, lexical or syntactical devices [12: 38-39].

Irina Arnold singles out three main devices of foregrounding such as the effect of defeated expectation, coupling (which implies parallelism), stylistic convergence [11: 81]. The Western stylisticians such as J.Douthwaite, G.Leech suggest two major devices: deviation and parallelism $[10 ; 12]$. In this paper, we state that the notion of prose poeticalness is connected with the principle of foregrounding.

Prose poeticalness as a principle and a feature of a literary text organization can involve the foregrounding of some devices that is dominant elements, and the deformation of the others [13: 277]. So, poetical prose is such prose where a number of devices of creating poeticalness are foregrounded. Poeticalness in short stories can be realized through the whole text or in some fragment(s) of it embracing one or several paragraphs. The location of such fragments in the story, e.g. in strong positions, is also significant.

The investigation of poeticalness in the short stories of the outstanding American writer Kate Chopin and the great British poet Dylan Thomas was summarized in the monograph [6]. The most frequent and the most foregrounded device of poeticalness turned out to be stylistic convergence. Nearly 40 stories by Chopin and Thomas which can be defined as poetical texts were analyzed, and convergence is functioning in over 30 of them. Also, stylistic convergence prevails in such strong position as the beginning, mainly in one or two 
initial paragraphs. A very short story “The Night Came Slowly” by Kate Chopin begins with stylistic convergence:

I am losing my interest in human beings; in the significance of their lives and actions. Someone has said it is better to study one man than two books. I want neither books nor men; they make me suffer. Can one of them talk to me like the night - the Summer night? Like the stars or the caressing wind? [14: 366].

This paragraph includes two anthropomorphic similes, a metaphoric epithet caressing wind and a metaphor, so typical for the writer's style. Besides, the antithesis people nature reveals the idea that nature is more pleasant to the narrator than people. Parallelism and syntactical repetitions emphasize this idea of contrast and the pragmatic effect of the convergence. This stylistic convergence can be characterized as tropeic-syntactical. In translation, the task is to correctly and fully render the metaphoric and contrasting ideas:

Я втрачаю інтерес до людей, до важливості їх життів та вчинків. Хтось сказав, що краще пізнати одну людину, ніж вивчити десяток книг. Мені не потрібні ні книги, ні люди; вони спричиняють мої страждання. Хіба хтось 3 них може розмовляти зі мною, як ніч - Літня ніч? Як зорі чи ласкавий вітер? (our translation).

Another device of poeticalness - intertextual allusions - prevails in Thomas's short stories. The biblical allusions are used in such texts as "The Tree", "The Visitor", and "A Prospect of the Sea". These stories become polysemantic and look like parables, as they are devoted to the problems of love, death, sense of life. However, it should be noted that allusions contribute to prose poeticalness when used in the text as a system, as the basis of the plot. A single allusion cannot create such effect. In the story "The Mouse and the Woman" the main character, a writer, tells about his beloved woman:

God, whom he had searched for in his loneliness, had formed her for his mate as Eve for Adam out of Adam's rib [15: 65].

Extended metaphors as elements of mythological thinking are usually components of convergences, but in the story "The White Eagle" by Chopin the text is based on the extended anthropomorphic metaphor. The sculpture of the eagle is depicted as a human being:

It was not an eagle of flesh and feathers but a cast-iron bird poised with extended wings and wearing an expression which, in a human being, would have passed for wisdom [14: 671].

Phonetic stylistic devices, syntactical repetitions, parallelism are also foregrounded devices of poeticalness. The functions of parallelism are similar to those of text paradigmatization formulated by W.Schmid. Parallelism is the main structural feature of poetry [5: 368]. Parallelism is not only the repetition of sentence structure, it can be observed on the paragraph level and text level. Different syntactical repetitions are also manifestations of parallelism. Victor Shklovsky justly characterized repetitions as "the rhyme of prose" [16: 114]. The main character of "The Recovery" by Kate Chopin regains eyesight after 15 years of blindness and bitterly regrets the time lost and the opportunities lost:

She might hope, and she might wait, and she might pray, but hope and prayer and waiting would avail her nothing [14: 483].

Parallelism interacts here with anaphora and polysyndeton, as in many other cases, to increase the emotional effect. Mick Short calls such principle of uniting the sentences "the parallelism rule", because "parallel structures invite the reader to search for meaning connections", they establish semantic similarities between the utterances [17: 14].

The results of our previous investigation of poeticalness in the classical British and American short stories of such great writers as Chopin and Thomas, we can state that our conclusions only partially coincide with the devices of poeticalness suggested by W.Schmid. While extended metaphors and allusions are singled out in both classifications, stylistic convergence is a characteristic device of the British and American authors, as distinct from Pushkin's stories. 


\section{Discussion}

\subsection{Rendering the stylistic convergences in the poetical description of nature in translation}

Prose poeticalness is realized in the classical short stories by Kate Chopin and Dylan Thomas, in the fairy tales by Oscar Wilde, in the metaphoric description of nature. Stylistic convergences, which include extended metaphors and similes, prevail in the initial paragraphs and in the middle of the stories. The style of Thomas and Chopin is characterized by anthropomorphic tropes which ascribe the physical properties and actions of people to the objects of nature such as the traits of appearance, the ability of talking, touching etc. Anthropomorphic metaphors are a characteristic feature of fairy tales in many countries; therefore, a wide use of this semantic type of trope in Wilde's tales is not a special deviation. His fairy tales "The Birthday of the Infanta", "The Selfish Giant", "and "The Star-Child" begin with metaphoric-phonetic convergences which include metaphors, similes and alliterations. The central sentence of the convergence in the well-known tale "The StarChild" contains the extended metaphor describing the earth covered with snow as a bride: "The Earth is going to be married, and this is her bridal dress". The translator Dariya Radienko skillfully rendered this image: “Земля наречена, і це їі весільне вбрання" [18: 222-223]. In translation Radienko applied the device of modulation (is going to be married - наречена) and literal translation of the metaphor.

In general, Dariya Radienko successfully renders the images in all fairy tales, applying literal translation or synonymic translation, in some cases, and retaining the conceptual aspect. However, she does not always reproduce alliterations, as for example, in the initial metaphoric-phonetic convergence in the fairy tale "The Birthday of the Infanta". Wilde describes nature on a fine summer day, and in one sentence, he uses the repetitions of sounds [s] and [t] as well as the sound combination [st] seven times: The tall striped tulips stood straight up upon their stalks, long rows of soldiers. The translator only partially rendered the sound effect: Високі смугасті тюльпани гордо виструнчилися на своїх стеблинах, наче вояки [18: 122-123]. In our opinion, the sound effect can be enhanced by using more words with alliterations: Високі смугасті тюльпани струнко стояли на своїх стеблинах, наче шеренги солдат. In such case, we repeat the key sounds 6 times.

Tetyana Nekriach, another translator of Oscar Wilde's fairy tales and plays, justly states that one of the challenges in the English-Ukrainian translation is the category of gender, which becomes particularly important in the context of the whole text [19: 9-10]. According to Peter Newmark, one of the best techniques of rendering original metaphors is reproducing the same image in the target language [20: 306-307]. This rule is particularly important in translating Dylan Thomas's original metaphors in interaction with phonostylistic devices. In our opinion, the sound similarity of semantically different words becomes one of the main factors for choosing certain notions as subjects and objects of metaphors [6: 25]. Such principle is very noticeable in extended metaphors, as in his brilliant story "The Dress". In this text the initial metaphoric-phonetic convergence is centered around the original metaphor mist-mother: But the mist was the mother to him [...]. The mist made him warm; he had the food and the drink of the mist on his lips; and he smiled through her mantle like a cat [15: 28]. Here the metaphor unites two semantically distant notions. From the context it is clear that the man is running, he wants to hide from the people following him. The mist comes from the sky and protects him. In the two sentences alliteration plays an important role - it is used 10 times in the semantically important words. Thus, not only metaphors should be retained in translation, but also sound repetitions.

The Russian translator of several Thomas's stories and poems M.Koreneva rendered the stylistic convergence, in particular these sentences, nearly literally: Но туман был ему как 
мать [...]. Туман грел его; питьем и едой лежал туман на его губах, и он улыбался под его роскошной мантией, как кот [21: 331]. Unfortunately, the translator made two serious mistakes. First of all, she changed the trope, metaphor into simile - как мать. In such way, she partially distorted the semantic unity between two objects, as metaphor shows constant similarity, while simile points to occasional likeness. Secondly, and more important, Koreneva did not take into consideration the gender aspect of translation: the word туман in Russian is of masculine gender, so the translation туман - мать is paradoxical. According to the suggested strategy, the first stage of our translation was rendering both components of the metaphor, i.e. the subject (tenor) and the object (vehicle). We chose the Ukrainian word імла, as it perfectly corresponds to the semantic and gender aspects of the target language. The second stage involved reproducing the sound effect more distinctly, so we added two words with the dominant sound [m]: Але імла стала йому матір'ю [...]. Імла зігріла його, напоїла і нагодувала, і він посміхався крізь іiі мантію, як маленьке кошеня. Using the diminutive word кошеня, we increase the pragmatic effect of protection and warmth for the man.

In many stories by Thomas, the words with alliteration are components of metaphors: breathing like a brass-band (дихав як духовий оркестр); big black boats of his boots (величезні чорні човни його черевиків) in “A Story". To render the semantics and pragmatics of the metaphors, we used the same phonostylistic device in translation of the words - components of metaphors and similes but with other sounds.

Another type of convergence in Thomas's stories - metaphoric-syntactical convergence, which is even more expressive. In his story "The Enemies" Thomas describes how a priest lost his way in the mountains and was frightened by darkness: Wherever he looked, the hills stormed up to the sky and wherever he sought to hide from the wind he was frightened by darkness. The farther he walked, the stranger was the scenery around him; it rose to undreamed-of heights, and then fell down again into a valley no bigger than the palm of his hand [15: 37]. The stylistic convergence is based on antithesis and contains hyperbole and meiosis emphasized by parallel constructions. The major function of this device of poeticalness is emotional; it reflects the feeling of fear and confusion in the mind of the priest. At the same time, the writer depicts the might and fantastic beauty of nature.

Also, many fairy tales by Wilde and short stories by Thomas include two or three stylistic convergences, usually of metaphoric-phonetic type. As distinct from them, only two stories by Chopin contain convergences with poetical description of nature. As a rule, the nature is described with the help of extended metaphors in one or two sentences: The air that swept across the sugar field caressed him with its warm and scented velvety touch [14: 334]. In translation the anthropomorphic metaphor and epithet were rendered completely, and alliterations as a device of poeticalness were retained, but with other sounds: Вітер, що долітав з цукрової плантації, пестив його теплим, духмяним і оксамитовим дотиком (our translation).

As our analysis shows, poetical description of nature in the short stories by Wilde, Chopin and Thomas is especially foregrounded in stylistic convergences containing anthropomorphic tropes and sound repetitions. Alliterations don't play only the auxiliary role, they help to create semantic unity between the trope components. Due to the location in strong positions and foregrounding, similes and metaphors realize a conventional conceptual metaphor NATURE IS A HUMAN BEING. At the same time, each author describes nature in a different way according to the individual style.

The contemporary American flash fiction stories are also characterized by wide use of stylistic convergence and its realization in strong positions - endings of the text. However, poetical descriptions of nature in the analyzed 30 flash fiction stories are not common. In the flash fiction story "Traveling Alone" by Rob Carney the author describes the admiration of nature. During the description of such natural phenomenon as the lightning, the metaphoric- 
phonetic-syntactic convergence is created at the end of the text: Out the window was this giant cloud that looked like a lightning factory. It wasn't shooting out lightning bolts. They were all happening inside the cloud, so these areas would suddenly flash in the middle ... then somewhere else ...then pmm pmm pmm pmm pmm all in a row. Like down there in the middle, gods were working with hammers and anvils and bellows and wearing those helmets with a little strip of glass to look out of. Like a cloudy furnace. Like the birthplace of light. Like maybe that's the way the universe looked in the womb [22: 225].

In this story the stylistic convergence is bigger and extends from the middle to the end of text. It is more emotional, expressive and poetical than in other flash fiction stories. It contains extended metaphor (gods were working with hammers and anvils), (cloudy furnace), (the universe looked in the womb), such phonostylistic devices as onomatopoeia ( pmm pmm pmm) and consonance (lightning - bolts - helmets - bellows), syntactic repetitions, namely parallelism and polysyndeton. With the extended metaphor, the author expresses the intensity of his admiration for the beauty of the lightning. Phonostylistic devices create melodic harmony, syntactical repetitions set the dynamics, but at the same time, the function of stylistic devices in this convergence is creation of aesthetic, emotional and poetical effect. The natural phenomenon is shown as something majestic and immense; the writer even imagines that the gods are involved in the creation of this natural phenomenon, so the conceptual metaphor NATURE IS GOD is actualized in this convergence.

In translation we try to render not only the original metaphor as a part of the stylistic convergence, but also the rhythm of the prose text, emotional and poetical effect in the description of the natural phenomenon: Та хоч де б ие було, в ілюмінаторі стояла величезна хмара - справжня фабрика блискавок. Вона не стріляла блискавками. Всі вони таїлися всередині хмари, тож ие місие спалахнуло... потім ще десь... потім бахбах-бах - усі підряд. Наче всередині боги прачювали - $i$ молотами, $і$ ковадлами, $i$ міхами, $i$, як $i$ заведено у зварювальному цеху, були в касках з невеликим скляним заборолом. То було достоту хмарове горнило. Пологи світла. Можливо, саме так виглядав усесвіт у лоні матері (our translation). The extended metaphors are rendered by literal translation, addition (як у зварювальному цеху; матері), lexical substitution (ілюмінатор; забороло; горнило) and omission. Onomatopoeia and alliteration are retained but with other sounds (pmm - бax).

\subsection{Rendering the lexical and stylistic devices in the poetical description of people in translation}

Klaudia Bednarova-Gibova justly emphasizes the importance of the literary translator's satisfaction at work, the emotional aspect of the translator's work [23: 68]. In our opinion, the translation of poetical prose can bring such professional satisfaction and pleasure. The texts of Chopin, Wilde and Thomas are distinguished by the original use of lexical and stylistic devices in describing people. The poetical description of people involves their appearance, physical beauty (Chopin, Wilde), spiritual qualities (Chopin, Thomas). One of the most interesting stylistic devices is biomorphic metaphor, which is based on ascribing the properties of natural objects to people. In Chopin's and Thomas's stories it involves the comparison with flowers, trees, water, whereas Wilde's fairy tales abound in comparison with minerals and flowers, By choosing the properties of such natural objects for the ground of tropes, the authors demonstrate their criteria of beauty, of spiritual importance. Stylistic convergences with these metaphors and similes are usually at the beginning of the texts. One of the most poetical stories "A Harbinger" ("Провісник") by Kate Chopin describes the main character Bruno, a young artist. He admires the beauty of young women whom he paints:

And then there was the gentle Diantha, with hair the color of ripe wheat, who posed for him when he wanted. She was as beautiful as a flower, crisp with morning dew. Her violet 
eyes were baby eyes - when he first came. When he went away he kissed her, and she turned red and white and trembled. Bruno sighed a lot over his work that winter. The women he painted were all like mountain-flowers [14: 145].

The stylistic convergence in two initial paragraphs can be called lexical-metaphoric as an important role is played by lexical units describing colors and metaphoric similes. The semantic field "Color" reflects the profession of Bruno. Yuliya Dudchak, the translator and a senior student of our department, rendered the emotional expression using the translation techniques of addition and morphological substitution of the trope components: e.g. beautiful - краса ивіла. This strategy helped the translator to retain the poetical, colorful effect of the fragment: Тоді він і зустрів тендітну дівчину на імя Діанса. Ї̈ волосся переливалось всіма відтінками зрілих колосків пшениці, і вона позувала для його картин, варто йому було лише забажати. Ї̈ краса иввіла, неначе квітка, омита ранковою росою. Коли вони вперше зустрілись, в ї̈ фіалкових очах світилася дитяча наївність. Коли вони прощзались, він поцілував ї̈, $і$ червоні та білі фарби заграли на ї̈ обличчі, вона затремтіла. Тієї зими Бруно сумував за своєю роботою. Жінки, зображені на його картинах, були прекрасні, наче гірські квіти [24: 271]. Another important translation technique used was the explication of the girl's name in the footnotes: Diantha - from Greek - means "divine flower". This symbolic name adds poeticalness to the whole story.

Biomorphic metaphors and similes in interaction with sound repetitions are an integral part of convergences in some other stories by Chopin. In "Two Summers and Two Souls" the extended metaphoric simile soul and senses are like petals are combined with alliterations of [s] and [1] in the trope components: It was in the country, where she lived, and where her soul and senses were slowly unfolding, like the languid petals of some white and fragrant blossom [14: 455]. The translator Alla Slisarenko successfully reproduced the poetical effect by using literal translation of tropes and retaining the same sound in alliteration: Вона жила за містом, і саме там ї̈ душа і почуття повільно розцвітали, неначе кволі пелюстки білої та запашної квітки [25: 269].

The fairy tales "The Star-Child" and "The Fisherman and His Soul" by Wilde contain two big stylistic convergences describing people's appearance. The ideal of boy's beauty for the writer is flowers - the daffodil, violets, and the narcissus: His lips, also, were like the petals of a red flower, and his eyes were like violets by a river of pure water, and his body like the narcissus of a field where the mower comes not [18: 230]. Dariya Radienko skillfully translated this sentence which is the center of convergence, rendered all the three similes and alliterations: Його ніжні вуста були наче пелюстки червоної троянди, а очі -мов фіалки на березі тихої річки. Він був схожий на дикий нариис, щзо вільно росте в нескошеному полі [18: 231]. Radienko also applied such techniques as additions of epithets in the target text - ніжні; тихої; дикий - and modulation in the second sentence, which add poeticalness to the description and emotional effect. For the description of the beautiful mermaid in "The Fisherman and His Soul" Oscar Wilde chose the comparison of her body with minerals and jewels, using the combination of six metaphoric similes with the repetition of the sound [1], which is a characteristic feature of his style:

Her hair was a wet fleece of gold, and each separate hair as a thread of line gold in a cup of glass. - Волосся в неї було наче вологе золоте руно, а кожний волосок - наче тонка золота нитка у кришталевій чаші [18: 158-159]. An interesting feature of translation is the abundant use of assonance, the 13-fold repetition of the sound [o] which gives rhythm to the description.

The functions of biomorphic similes and metaphors in Dylan Thomas's stories lie in expressing the identity of physical processes in the human body and in nature: Life would go on in the veins, in the bones, in the binding flesh that had their seasons and weathers [15: 36]. An important spiritual idea is foregrounded in the biomorphic simile in the story "The Visitor": Life would sprout up again like a flower through a coffin's cracks [15: 27]. The 
writer states the victory of life over death, and the image of such victory is a flower. Like in other stories by Thomas and in Chopin's texts, the components of the trope are united by alliterations of [f] and [k]. We rendered the verbal and sound images in translation, but used another sound for semantic unity: Життя проросте, наче квітка, через тріщини у труні. This simile reflects one more aspect of poeticalness in Thomas's philosophy that is comparing spiritual notions and values with natural objects: his God grew like a tree from the appleshaped earth, giving bud to his chidren [15: 43]. In translation we retained the image and the components of the extended simile: його Бог виростав, як дерево із землі, схожій на яблуко, і дарував бруньки своїм дітям.

In flash fiction stories the description of people with the help of the lexical and stylistic devices is also an effective method of creating the imagery and expressing the poeticalness of the text. The story "Justice - a Beginning" by Grace Paley, which tells how a woman - a member of the jury after the court hearing reflects on the concept of justice - contains the stylistic convergence including two extended metaphoric similes and alliterations. In this text the author describes the appearance of the mother of a man who has just been sentenced: She leaned on the witness bar, her face like a dying flower in its late-season, lank leafage of yellow hair, turning one way then the other in the breeze and blast of justice. Like a sunflower maybe in mid-autumn, having given up on the sun, Faith thought [22: 124]. Due to the metaphoric similes (her face like a dying flower in its late-season; like a sunflower maybe in mid-autumn, having given up on the sun) and alliteration of the sound [1] the author expresses the feelings of pity to the woman. The tropes are conceptual in character and reflect conceptual metaphor OLD WOMAN IS A WITHERED FLOWER that is the variation of conceptual metaphor WOMAN IS A FLOWER. In our translation we try to render metaphoric simile and convey the expressiveness and poeticalness of the text: Mamip притулилась до трибуни свідків. Обличчя ії було схоже на зів 'ялу квітку в кіниі сезону. Довге солом'яне волосся жінки майоріло від пориву вітру та справедливості. Наче соняшник, який десь у середині серпня засох від сония, подумала Фейт. The metaphoric similes are rendered with synonymic change of epithet (dying flower - зів'яла квітка; yellow - солом'яний). The alliteration is retained with another sound [c] that resembles the whistling of the wind and enhances the impression of the text and its imagery.

The story "Bullhead" by Leigh Wilson tells a story of a woman who goes to the lake, where her native town was and she met the love of all her life, and drops a coin in memory of her happy years. Though the woman is married, has children, still her memory of love is strong. The text contains the stylistic convergences in two strong positions - in the introductory and final paragraphs united by frame repetition. The final paragraph contains the tropeic-syntactic convergence: Every story is true and a lie. The true part is this one: Love and the memory of love can't be drowned. The lie part is that this is a good thing [22: 100]. The stylistic convergence includes oxymoron (every story is true and a lie), metaphor (love and the memory of love can't be drowned), parallelism and antithesis (the true partthe lie part) creating strong pragmatic effect. In translation we retained the components and image of convergence: Кожна історія є правдивою та неправдивою водночас. Правдивість иієї історії полягає в тому, що кохання, як і пам'ять про кохання, не можна затопити. А неправда у тому, щзо ие добре. In the process of translation, we applied a complex of translation transformations, so the original metaphor is rendered and translated literally; oxymoron is rendered by the grammatical substitution of the noun by the adjective (a lie - неправдива).

As a result of our research, we can formulate the structure and mechanism of creating extended metaphors and similes. Dylan Thomas, Oscar Wilde and such contemporary writers as John Updike, Grace Paley choose the words for trope components from the same semantic field as the object (vehicle) of the trope. Such mechanism can be defined as the chain of images: one image leads to another. If the father is a tree, his children are birds on the tree 
(Updike). If the owner of the pub is described as a wolf, then he has black fangs and a claw, he can eat a mountain sheep (Thomas). If the lightnings are made at the factory, so gods working there have instruments - hammers, anvils (Carney). If the Earth is a bride, it has a bridal dress (Wilde). In some contemporary stories tropes are extended by epithets, as the woman is depicted as a dying flower in Paley's story. An important role belongs to sound repetitions in the extended metaphors because they unite semantically different notions: boats-boots, mist-mother (Thomas); lips-petals (Wilde). But in general, extended tropes are components of convergences, they are like minipoems in a prose fragment.

\subsection{Allusions as a device of poeticalness}

It is necessary to differentiate between intertextual and intermedial allusions. Intertextual allusions involve references to the texts of other authors, whereas intermedial allusions are based on the semiotic transfer from one sphere of art to another. In particular, they include allusions in a literary text to painting, architecture, sculpture, cinema. Among the analyzed stories allusions as devices of creating poeticalness are widely used in Dylan Thomas's stories "The Tree", "The Visitor", "The Prospect of the Sea". Firstly, we would like to single out intermedial allusions. These allusions are explicit and function as components of intermedial similes. In the story "A Prospect of the Sea" the main character, a boy, in his dream is flying over Europe. Among the places he sees is an empire broken like Venus [15: 8]. In this sentence Venus is the metonymy of the well-known statue of the Venus de Milo. The technique of translation to be used is explication. However, in the existing Russian translation Yuriy Komov did not clarify the simile and metonymy: предплечья империи, обрубленного, как у Венеры [21: 306]. Our interpretation of this syncretic trope is the following: the writer means a country partially destroyed, like the arm in the statue of Venus. We suggest the translation with addition and explication: зруйнована імперія, подібно до розбитої статуї Венери Мілоської. Another intermedial allusion refers to a well-known architectural monument: Lame like Pisa, the night leaned on the west walls [15: 8]. The same technique of explication is suitable here: Кульгава, як Пізанська вежа, ніч притулилась до західноі стіни.

Intertextual allusions involve mainly references to the Bible and Celtic mythology. Similar to intermedial allusions, intertextual references are often components of tropes metaphors, similes, hyperboles. The story "The Tree" contains the biggest amount of biblical allusions among all Thomas's prose texts: over 30 names of people and events and 19 intertextual tropes. The writer connects the events or people in Wales with the biblical characters and landscapes: "The first tree. The first tree you told me of. In the beginning was the tree, you said. I heard you," the child shouted. "Bethlehem," said the idiot to valley, turning over the sounds of the word and giving it all the glory of the Welsh morning [15: 4647]. Thomas ascribes divine character to nature: As he unfolded the story of the twelve stages of the cross, the tree waved its boughs to the child. An apostle's voice rose out of the tarred lungs [15: 47]. The Russian translator Maya Koreneva adequately rendered the intertextual metaphors and epithet: Пока он вел рассказ о двенадцати остановках на крестном пути, дерево ветвями приветствовало ребенка. Голос апостола поднимался из глубин просмоленных легких [21: 259].

Unfortunately, this experienced translator did not render correctly the intertextual allusion in the story "The Visitor". The main character of the story, a writer, is seriously ill. Two people are taking care of him, one of them a woman named Rhianon: She had gone and returned with food, as simply as a maiden out of the old Testament. Her name meant nothing. She had a strange name out of the Bible. Such a woman had washed the body after it had been taken off the tree [15: 29]. The difficulty lies in the allusive name. In the text Rhianon is ascribed the same features as Mary in the New Testament, who took off the body of Jesus 
Christ from the cross and washed his body. That is why it is a wrong trigger for the reader and an implicit allusion, especially for the Ukrainian reader. A person who has background knowledge of the Celtic mythology may be familiar with the fact that Rhianon is the name of one of the most important Celtic goddesses, the goddess of fertility, the symbol of light and life [26: 38]. Of course, the name is absent in the Bible. However, Koreneva ignored the allusion and translated the fragment literally: Она уходила и возвращалась с едой так же просто, как ветхозаветная дева. Ее имя не значило ничего. Она носила странное имя, похожее на библейское. Такая женщина омывала тело, снятое с креста [21:268]. The strategy of translating implicit allusions presupposes giving comments in the footnotes. This technique was not used. At the same time, the allusive name means the connection of the Celtic and Biblical legends, the connection of two famous characters, it performs intercultural function. Comparing the woman in the story with the biblical Mary, Thomas emphasizes the importance of Rhianon for the dying man, makes her the symbol of mercy and sympathy. In such a way, the allusions as the device of prose poeticalness create a strong emotional and spiritual effect. But such pragmatic effect could be achieved in the target text under the condition that the allusion is explained.

\section{Conclusions}

The conducted investigation reveals that the devices of prose poeticalness depend on the author's individual style and on the historic as well as literary period. The short stories of the beginning and the first half of the XXth century represented by the works of Kate Chopin and Dylan Thomas and by the fairy tales of Oscar Wilde are distinguished by the use of stylistic convergences as the most foregrounded device of prose poeticalness. Besides, Thomas's stories and Wilde's tales contain two or three devices of this type, mainly in such strong position as the text beginning. In the contemporary flash fiction stories, convergences embrace smaller text fragments and are normally located in another strong position - the ending.

From semantic point of view, the difference in the devices of prose poeticalness lies in the following. In classical literature, stylistic convergences contain, as a rule, extended anthropomorphic metaphors and similes, which are the core of such convergences. The majority of convergences are of tropeic-phonetical type. Alliterations as a device of poeticalness add rhythm and musical effect to the text fragments. The reader can feel the author's admiration of the beauty of nature (Chopin, Wilde), the might of nature (Thomas). That is why convergences function as an important element of emotional, poetical description of nature.

As distinct from the stories by Chopin and Thomas, the analyzed contemporary flash fiction stories contain extended biomorphic similes and metaphors as the central parts of convergences. In some stories (Paley, Updike) these tropes are used for poetical and emotional description of people, their family relations, and their behavior in difficult situations. In such way, the contemporary authors foreground the idea of sympathy, love, tolerance. Another distinctive feature of poeticalness in flash fiction is that phonostylistic devices are used less often and that convergences are more varied in their structure as they usually contain the interaction of tropes with syntactical parallelism, antithesis, gradation, play of words.

From translation point of view, poeticalness of prose is a complex and comprehensive notion. As no detailed analysis of poeticalness has been conducted, we can suggest the following results of our investigation of rendering prose poeticalness in translation. We concentrated attention on the poetical fragments with stylistic convergence, the most noticeable device of poeticalness. Extended metaphors and metaphoric similes constitute the core of convergences. In the Ukrainian translation of Oscar Wilde's fairy tales and the short 
stories by Kate Chopin the linguistic components of tropes and their conceptual character were retained by using literal translation, synonymic substitution of the components and change of trope. The drawback in the Russian translation (M.Koreneva) of some stories by Dylan Thomas involved ignoring the gender aspect in translation of the name of the natural phenomenon, i.e. literal translation prevailed. As the second component of the convergences in the classical short stories and fairy tales is alliteration, the Ukrainian translator of Wilde's tales and the Russian translators do not always render the phonostylistic devices as parts of extended tropes. Thus, the semantic and sound unity of the subject and object of metaphors and similes is partially lost.

We consider that the strategy of translating tropeic-phonetic convergences with the aim of retaining and foregrounding prose poeticalness should be as follows: literal and exact translation of trope components with the same sound in trope components (Thomas) or with the same phonostylistic device, i.e. alliteration, assonance, onomatopoeia, but with a different sound which is dominant in the extended trope and the convergence.

Special attention in our research is devoted to translating intertextual allusions, which are a special device of poeticalness in Thomas's short stories. The writer introduces mythological elements into modern life, thus he creates intercultural connections and emphasizes the spiritual aspects of human behavior and thinking. While explicit allusions as proper names are translated correctly and adequately, the implicit allusions from the Celtic mythology, in particular proper names (Rhianon) and symbolic places and objects are rendered in the Russian translation only literally, without comments. As a result, significant pragmatic effect is lost for the reader. Therefore, the strategy of translating implicit biblical and mythological allusions based on the Celtic legends should include obligatory comments in the footnotes while explicit proper names.

The prospect of further research lies in the investigation of devices of prose poeticalness in the novels of the contemporary British, American and Canadian writers and the techniques of rendering these devices in translation.

\section{References}

1. R. Barthes, Selected Works: Semiotics. Poetics (Progress, Moscow, 1989)

2. E. Pound, A Retrospect. Twentieth-Century American Poetics. Poets on the Art of Poetry (McGraw-Hill, New York, 2004)

3. T. Hermans, Literary Translation. A Companion to Translation Studies (Multilingual Matters Ltd., Clevedon, 2007)

4. K. Bednarova-Gibova, Non-Literary and Literary Text in Translation (Presov University, Presov, 2012)

5. R. Jakobson, Closing Statement: Linguistics and Poetics. In: Thomas A. Sebeok (ed.) Style in Language (The M.I.T. Press, Cambridge, 1964)

6. A.Yemets, Investigating Poeticalness of Prose (Lambert Academic Publishing, Saarbrucken, 2012)

7. L. Caroll, Through the Looking Glass, and What Alice Found There (in English and Ukrainian) (Folio, Kharkiv, 2017)

8. W. Noth, Handbook of Semiotics (Indiana University Press, Bloomington, 1995)

9. W. Schmid, Prose and Poetry in Povesti Belkina, Canadian Slavonic Papers, 210-227 (1987)

10. J. Douthwaite, Towards a Linguistic Theory of Foregrounding (Edizion dell'Orso, Alessandria, 2000)

11. I.V. Arnold, Stylistics. Contemporary English Language (Nauka, Moscow, 2004)

12. G. Leech, Language in Literature: Style and Foregrounding (Pearson, Harlow, 2007) 
13. Yu. Tynyanov, Poetics. History of Literature. Cinema (in Russian) (Nauka, Moscow, 1977)

14. K. Chopin, The Complete Works (Louisiana State University Press, Baton Rouge, 1997)

15. D. Thomas, A Prospect of the Sea and Other Stories and Prose Writings (Dent, London, 1966)

16. V. Shklovsky, On the Theory of Prose (in Russian) (Sovetsky Pisatel, Moscow, 1983)

17. M. Short, Exploring the Language of Poems, Plays and Prose (Pearson Education, Edinburgh, 1996)

18. O. Wilde, The Canterville Ghost (in English and Ukrainian) (Folio, Kharkiv, 2008)

19. T.Ye. Nekriach, "The Underwater Reefs" of Literary Translation: Rendering Grammatical Gender as the Plot Component, Inozemna Filologiya 1, 9-12 (2015)

20. P. Newmark, A Textbook of Translation (Pearson Education Ltd., Harlow, 2008)

21. D. Thomas, Adventures in the Skin Trade (in Russian) (Azbouka-klassika, SaintPetersburg, 2001)

22. Flash Fiction Forward 80 very short stories (W. W. Norton \& Company, London, 2006)

23. K. Bednarova-Gibova, Exploring the Literary Translator's Work-Related Happiness: the Case Study of Slovakia, Across Languages and Cultures 21, 67-87 (2020)

24. K. Chopin, A Harbinger (in Ukrainian), Vsesvit 1-2, 271-272 (2013)

25. K. Chopin, Two Summers and Two Soules (in Ukrainian), Vsesvit 1-2, 269-271 (2013)

26. K.M. Korolev, The Pagan Deities of the Western Europe (in Russian) (Eksmo, Moscow, 2005) 